\title{
Muslim Pilgrimage as Education by Experience
}

In Christian tradition, pilgrimage is connected with hardship and sacrifice. It has been used as a penance for penitents. The pilgrimage itself is a kind of sacrifice. The Muslim pilgrimage is different. The atmosphere is serious, but full of confidence. The pilgrimage strengthens faith through the spirit of community with millions of other Muslims, who share the same faith. In that respect it resembles the mass meetings of revivalist Christianity. Ghulam Sarwar, Director of the Muslim Educational Trust in Great Britain, has written about hajj, the pilgrimage of Islam: 'The occasion may rightly be called the Annual International Muslim Assembly' (Sarwar 2003: 74). The pilgrimage means that Muslims are brought together in action, walking, running, praying, throwing pebbles, slaughtering and, most importantly, standing for half a day in the desert. All these experiences are used for education through experience. The pilgrimage is an opportunity to educate the Muslims in religious matters. It is a typical example of 'learning by doing.'

This article will elaborate the content of this education as it is performed today. The purpose is twofold: to show how well the pilgrimage is fit for education and to investigate how this opportunity is utilized today. The account is built on contemporary theological literature about Islam. Most of the works are introductions to Islam, written by well-known and esteemed scholars. They are meant to give elementary information about Muslim life. The purpose is not to decide what is right or wrong in the performance, or in the interpretation of the rituals. The purpose is to describe what is taught by the religious leaders today. They seem to regard some traditions as dubious, as they might be perceived as superstitious. They might also have been accused of this by Western scholars. That does not mean that they are superstitious. The aim of the article is only to submit a discussion and an analysis of a trend in contemporary Islam. 


\section{Old traditions, new interpretations}

The Muslim pilgrimage has derived its content from old religious traditions, established before the time of Muhammad (Wellhausen 1927: $68 \mathrm{f}$.). There are a lot of instructions for pilgrimage in the Quran, which confirm and explain these old customs. For Muslims it is important that Muhammad's message was not a new but an old religion, the original religion of mankind. The correct religion of Adam and Abraham should be restored by Muhammad's revelations. Therefore Muslim authors underline that 'many of the rites of the Hajj go back to the Prophet Ibrahiim'. (Hamid 1990: 126.)

Old religious traditions from the Arabian Peninsula were incorporated into the 'new' religion and perhaps no aspect of Islam contains so many elements from the past as the pilgrimage. They must be preserved as a sign of continuity and reinterpreted as a sign of the importance of the revelations of Muhammad. Is the Islamic 'adoption' of old pilgrimage rites merely a way to create connections between the new religion and the old traditions of Mecca? Is it only a way to prove that Islam is a restoration of an original religion? Are the old traditions, on the contrary, so strange and unlike the message of Muhammad that there is an incongruity between them? That is what 'orientalist' (in the sense which Edward Said has ascribed to the word) scholars have asserted. In 1951, Gustav Edmund von Grunebaum, a well-known Middle East scholar from the University of Chicago, wrote the following:

The very tenuous relation between the old ritual and the new religion is striking. Aside perhaps from the ceremonies centering in the Ka'ba, there is no attempt at an ideological or even mythological integration. The practice and precept of the prophet constitute the only link between Islamic and pre-Islamic worship. Nothing in the doctrine of Islam suggests the wuquf in Arafa as the culmination of a specifically Muslim pilgrimage. (Grunebaum 1988: 35, first published 1951.)

This is a misleading statement. There have been many attempts to connect the new religion with the old ritual, which also has been changed in many ways to annihilate offensive elements. The heritage created an important mission for Muslims. They had to keep and reform the old rites and a British scholar writes, half a century later, about the reforms of pilgrimage:

They changed them in four ways: by cleansing them of their polytheist associations; by combining them in a single act of devotion. ..; by mak- 
ing it into the culminating spiritual aspiration of every Muslim; and by attaching its places and events to the roots of monotheism, seeing 'Arafat as the site of the reunion of Adam and Eve after their expulsion from Paradise, Mina as the spot where Abraham sacrificed a ram in place of his son Ishmael, and the Ka'aba as the sacred house founded by Adam and restored by Abraham and Ishmael, with the tombs of Hagar and Ishmael beside it. (Stewart 1995: 90 f.)

The Muslims had to preserve the old traditions but adapt them to the right design and teach people the new interpretations of the old customs. This is what still continues. The 'cleansing from polytheist associations' is completed in theological considerations but far from accomplished in practice. The struggle for reinterpretations has been in progress since the time of Muhammad. According to Grunebaum, the standing at Arafa (or Arafat) has no connection with 'the doctrine of Islam'. According to Muslims, it is quite possible to interpret the wuquf at Arafa as an adequate expression of the new faith, and today it is on the contrary regarded as the most apparent expression of the true Islamic faith. Other parts of the pilgrimage are depreciated or opposed, but the standing at Arafa is emphasised as the climax and the only obligatory element of the pilgrimage.

Old traditions create new objections when times change. Traditions are opposed or interpreted in a new way. Some of the objections have their origin in Western scholarship. Western scholars have written that kissing the black stone in Kaba is a remnant of the old cult of holy stones. We know that a cult of holy stones had been common in the Middle East in antiquity. In Israel, there were for example the stones urim and tummim (1 Sam. 14:41). Circumambulation around Kaba resembles what the priests of Baal did according to the Bible (1 Kings 18:26). God did not answer those prayers. Christians seldom believe that the Devil appeared physically when Christ was tempted in the desert (Matt. 4:1). Do Muslims still believe in a Devil with a carnal and corporeal body, which might be chased away with pebbles? Kissing the black stone, the stoning of Satan, the sacrifice of animals, cutting hair and beard, is it not all superstition or cruel remnants of an old religion with another view of God? Why shall we sacrifice goats to God? Does he demand bloody sacrifices?

This double dependency, on old customs and correct orthodoxy, has characterized Muslim pilgrimage throughout its history. It was obvious from the beginning that old customs must be opposed and superstitious belief from the time before Muhammad must be rejected. In modern times new problems 
have appeared when Muslim scholars have discovered possible misinterpretations of the traditions of pilgrimage. Those questions raise discussions among Muslims in our time. It must be underlined once again that all this is an account of current Muslim theological discussions and opinions. The intention is to describe, not to evaluate or propagate any view of the problem as right or wrong.

The distinguishing quality of the Muslim pilgrimage is connected to almost all parts of the faith or the creed and salvation history, from the creation of the universe to the Last Judgement. Let us follow the pilgrim through the events of the days in Mecca and Medina to see how the content of Islamic belief is called up through places, buildings, actions and obligations in Mecca and its neighbourhood. One type of information is available in the textbooks about Islam which have been written by western scholars. Another type is to be found in the books of Muslim authors, written from within, generally with the conviction that Islam is the first and last religion of mankind, the original religion which has been restored through the revelation of the Quran. They find plenty of opportunities in the pilgrimage to propagate this creed, but the different parts must then be valued and interpreted according to their instruction.

\section{Guide-books}

There are a lot of manuals and books with information about the Islamic faith which describe the pilgrimage for Muslims and non-Muslims. This article is built on modern guides to Islam and Islamic pilgrimage, published in the West to prepare Muslims for the pilgrimage and help non-Muslims to know and understand it. The most important purpose is perhaps to annihilate objections and misunderstandings about the pilgrimage, in Islam called hajj. In 1957, Dr Muhammad Hamidullah at Centre Culturel Islamique in Paris published an Introduction to Islam, which then appeared in a lot of editions in about twenty different languages. It can be compared with a later book from the New World, What everyone should know about Islam and Muslims by Suzanne Haneef, published in 1979 by Kazi Publications in Chicago. Suzanne Haneef is a Muslim convert from Christianity who, after her conversion, has been responsible for Islamic education in the USA. Hammudah Abd al-Ati's (1928-76) book Islam in Focus is also regarded as a valuable introduction. The third, revised edition was published in 1999 and has been translated to Swedish among a lot of other languages. Mawlana Mawdudi (1903-79) is known as a 
representative of Islamistic theology. His teaching and opinions are expressed in Fundamentals of Islam (1st ed. 1975) and Towards Understanding Islam (1978). The second book has also been published in Swedish and Norwegian. Another modern book is Ghulam Sarwar's Islam, beliefs and teachings (1st edn 1980, 7th 2003). Ghulam Sarwar is director of The Muslim Educational Trust in Britain and the book has been printed in more than 250,000 copies.

But there are also some comments on the Western text-books about Islam referring to a lingering 'orientalism' in the description of the Muslim pilgrimage. An important example is the already introduced Muhammadan Festivals by G. E. von Grunebaum (1909-72), a scholar who taught at the Universities of Chicago and California. His book was first published in 1951, but was then reprinted many times. The elementary textbooks on Islam are not always so exhaustive in their descriptions of pilgrimage, but what is written might nevertheless be misleading, because the account reflects rites that are under debate or disappearing. All scholars have not always noticed how the Muslims have changed their rituals, instructions, and interpretations of old customs.

\section{The state of ihram}

When the pilgrims arrive at Mecca 'they enter into a state of consecration known as ihram' (Haneef 1979: 52). They must change clothes. Male pilgrims shall wear a dress unique to hajj, consisting of two pieces of unsown cloth. No specific garment is prescribed for women but they must cover their bodies, 'leaving only their faces and hands exposed' (Haneef 1979: 52). What is the explanation of this custom? According to Grunebaum it is an ancient Semitic ritual:

The dress, identical with the hulla, the shrouding garments of the pagan Arabs, and again the dress of the gods, is in all likelihood the sacred dress of the old Semites. The upper garment of the High Priest in the Old Testament was seamless. The ephod of the Jewish priests, worn around the hips, and the me'il, worn around the shoulders, were white.

(Grunebaum 1988: 27.)

It is obvious that the ihram dress is a heritage from times before Muhammad, although some scholars assert that people in olden times were running around Kaba naked and that this was strictly forbidden by Muhammad's revelations (Mawdudi 1978a: 211; Tabbarah 1978: 173). The Muslim writers have 
no objections to the dress and give edifying explanations of the custom. The dress shall express equality in front of God. Rich and poor, well-known and unknown, powerful and suppressed, all are equal during the hajj. When the Muslim comes to Mecca

... a deep sense of smallness and insignificance comes to him, and all the trappings and defences of his ego fall away as he realizes that God alone is great and that none of His slaves can bring any of his worldly props and privileges with him to confront the glory and majesty of his Lord (Haneef 1979: 55).

It seems to be very important to experience equality as servants to the Lord in a way which reminds the pilgrims of the first time in Eden and future life in Paradise. For the standing at Arafa it is also extremely important that everybody is dressed in the same way. All Muslims seem to perceive the standing as an anticipation of the Last Judgement and for them it is obvious that all human beings then will be dressed in white cloth. According to Muhammad Hamidullah the Muslims demonstrate this equality already on earth during the pilgrimage:

The world brotherhood of Muslims manifests itself in the most vivid manner. The believers, without distinction of race, language, birthplace, or even class, feel the obligation to go there, and to mix with one another in a spirit of fraternal equality. They camp together in the desert, and perform their religious duties in common. (Hamidullah 1974: $73 \mathrm{f}$.)

All pilgrims are prohibited to use perfumes or to do any damage to any living thing, whether plants or animals, in the territory of Mecca. They must not carry arms, quarrel or insult other persons. Marriage and sexual intercourse is forbidden. They are forbidden to wear shoes covering ankles, cut hair or clip nails. Men must not cover the head, women not the face (Sarwar 2003: 75). This is a life without evil and carnal relations. All this resembles life in the original paradise of Eden and the future paradise in heaven. The pilgrims live like angels during a short time on earth as a preparation for a similar life in eternity. It is an education by experience about the final goal of human beings. 


\section{Kaba}

The Kaba is an important building in Mecca, especially during the hajj, when millions of Muslims visit the city. For the Muslims, Mecca is the centre of the world and Kaba is the centre of Mecca. The building is regarded as the oldest temple in the world (Tabbarah 1978:172) by Muslims, as it is built and reconstructed by the greatest prophets:

The Quran (3:96) does not exaggerate when it says that this is the oldest House in the world dedicated by mankind to God and to the cult of monotheism. If one were to think only of Abraham - who according to the Islamic tradition, was but the restorer of the edifice erected originally by Adam - it would still be older than the temple of Jerusalem, constructed by Solomon. No other place of worship older than the Ka'bah of Mecca, is known to be still functioning. (Hamidullah 1974: 71.)

Here appears the idea of Adam as the master builder of Kaba. According to Islamic tradition Adam had built the first Kaba. It was destroyed but rebuilt by Abraham and Ishmael. Some authors assert that only Abraham has built it (Mawdudi 1978b: 139). It is often said that Abraham is the most important person as origin of the actions during the hajj (Hamid 1990: 126), but that it is an exaggeration to emphasise the connection between Islam with the original religion of mankind. In rites and devotion Adam is also important as the person who built the first Kaba and met his wife outside the city. Hagar and Ishmael are also significant for the rites.

The prophet Muhammad himself has given the pilgrimage its current design in many parts, but that is not so often mentioned, in order not to support Western scholars who assert that most of the rites are created by Muhammad and is an imitation of his Farewell Pilgrimage in 632 (Grunebaum 1988: 18). The history of the world, from the creation of man and universe, is repeated during the hajj rites, but Abraham is perhaps the most important because he is considered as origin of the real and correct cult in Mecca.

\section{The Zamzam well}

Ishmael is said to have helped his father in the construction of Kaba. It is not said if that happened before or after the incident when he was saved from death by God who helped his mother Hagar to find the spring of Zamzam. A 
Western author has written that the 'child' Ishmael was saved from death by the spring (Armstrong 1993: 254). According to the Bible Ishmael was thirteen years old when he and his mother were expelled from their home and forced to live in the desert, so he was hardly a child. Hagar got some water in a bag to take with her, but soon there was no more water, so Hagar began to seek for a well and finally found the Zamzam well. No Muslim has denied that Ishmael was thirteen years old when he was driven away and he might have been old enough to help his father in the reconstruction of Kaba before the expulsion. Muslims also assert that Ishmael was the son who should have been sacrificed:

Although the Old Testament (Gen. 22:1-2) refers to Isaac as the object of the intended sacrifice, the error in this account is made clear by the fact that it refers to Isaac as Abraham's "only son," when it is an historic fact that his son Ishmael was born several years before his son Isaac (Haneef 1979: 51).

It is interesting to note how the idea of 'historic fact' here is used. That Ishmael was born 'several years' before Isaac must be supported by the Bible. In that respect the Bible is reliable, but it is wrong in its statement that Ishmael was the intended sacrifice. Muslims can refer to the Quran, sura 37: 112/112, where it is written that Abraham got the promise about Isaac as a reward for his readiness to sacrifice Ishmael.

The story about the well in the desert is proof of God's providence and will teach us to trust it. Suzanne Haneef tells us:

\begin{abstract}
Abraham brought his wife Hagar (Hajirah) and son Ishmael to the barren valley of Mecca, then a desolate, uninhibited spot surrounded by stark lava hills, and left them there at God's command. When their supply of water was exhausted and the child began to cry with thirst, Hagar began a hurried search for water, running back and forth seven times between two small hillocks. Her search proved futile, but when she turned back to her son, God revealed to her the spring of Zamzam flowing at his feet. It has flowed continuously since that time. The presence of water in the midst of the inhospitable desert attracted settlers to the spot which in time became the city of Mecca. In later years Abraham together with his son Ishmael built the Ka'aba very close to the spring. (Haneef 1979: 55.)
\end{abstract}




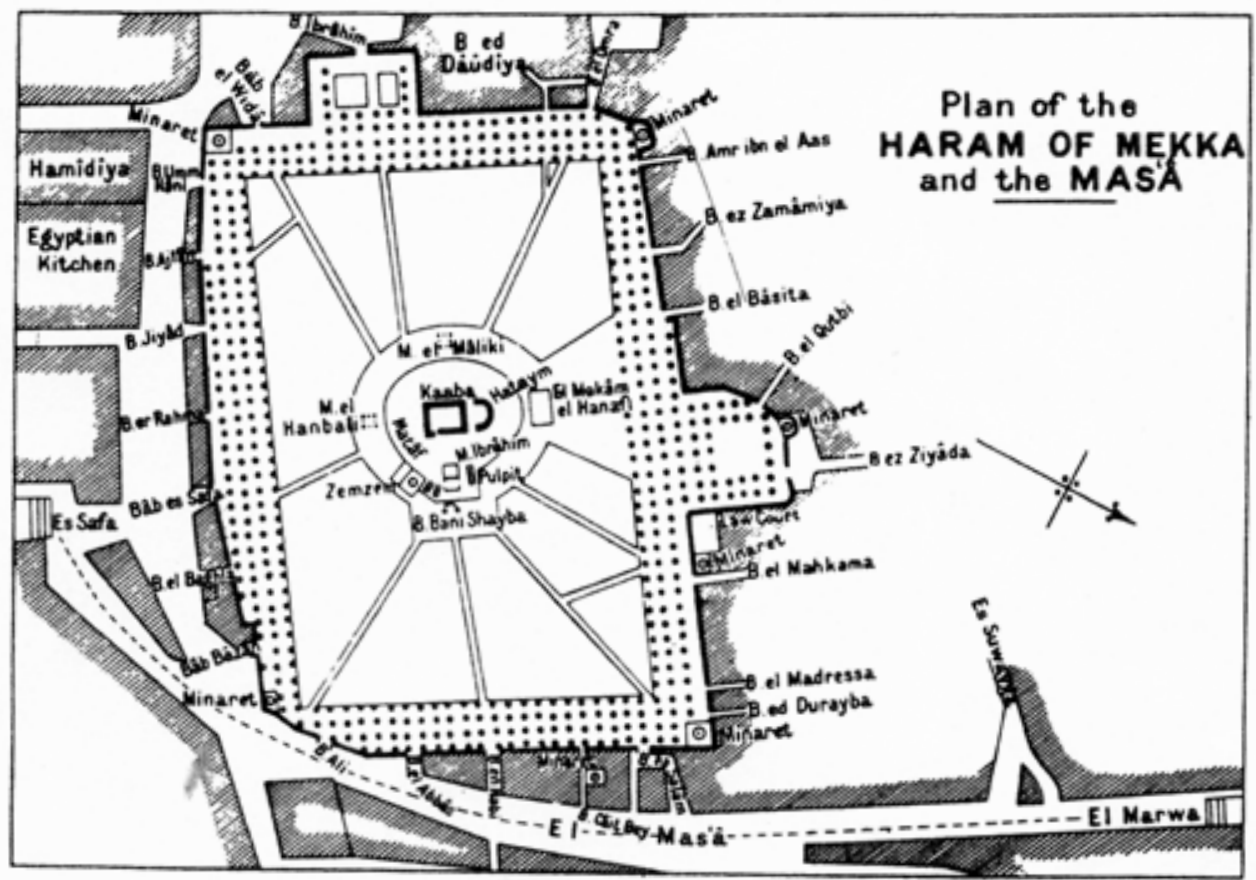

Plan of the Haram of Mekka (von Grunebaum 1988).

According to this text, the spring of Zamzam is the very reason for the existence of the city of Mecca. The pilgrims are obliged to run seven times between the hills Safa and Marwa and this running is called sa'i. It is not unlikely that Mecca got its location because of the well, and that it is a reminder of the cult of holy wells in Arabia before Muhammad. Many pilgrims have still a deep reverence for the water. They soak cloth in the water, dry it in the sun and take it home to be used as their future shrouding. They buy bottles with the Zamzam water to take home 'for healing purposes' (Hitti 1970: 38). Pilgrims drink the water (Waddy 1982: 21) and the spring is said to be 'bathed in by the pilgrims who attend the hajj' (Geaves 2006: 122).

The running can be perceived as an act of reverence for the holy water in the well. The rites around the Zamzam well thus also need to be interpreted in a more 'Islamic' way. Hagar is an ideal for all women and all mothers. That is why Muslims shall perform sa' $i$ : 'So one repeats this act in the same place where Hagar did it, to pay homage to maternal love and in thanksgiving for the mercy of God' (Hamidullah 1974: 73). She cared about her son and trust- 
ed God. She was in despair but was delivered from destruction. We must always trust God, also in hopeless situations. Not a word about holy water, bath or drinking.

This is a typical example of the modern trend to deduce ethical education from every detail and evade associations to the cult of created objects. The rite shall give them time to remember Hagar, Ishmael and their terrible situation in the desert. The possibility of divine protection in difficult problems seems to be proved by God's salvation of Ishmael. Ishmael is also important as the connecting link between Abraham and Muhammad and for that reason a proof of the faith in Islam as the religion of Abraham and of Adam.

\section{The circumambulation in Mecca}

Mecca is also the city of Muhammad. He was born there, received his first revelations in the neighbourhood and began to preach the restored message of Abraham among the inhabitants of Mecca. From that place he made his nightly journey to Jerusalem and in 624 he had a revelation about Mecca as the correct direction for prayer, the qibla. Memories of Muhammad meet the Muslim pilgrim in several places, but Kaba is the most important symbol of monotheism, because Muhammad is said to have annihilated all traces of idolatry there:

Although the central purpose of the Ka'aba was always acknowledged to be the worship of God, for a time, beginning long before the birth of Prophet Muhammad, it was the centre of the idolatrous worship of the pagan Arabs. Inside it stood a vast number of idols which were worshipped together with God. When the prophet gained the final victory over the Meccans, he demolished the idols and the Ka'aba was again restored to its original sacred purpose, that of worship of Almighty God alone. (Haneef 1979: 53.)

The pilgrim shall 'greet' the Holy Mosque of Kaba by performing a brief salat or prayer and circle around the Kaba seven times. These are old rituals according to Grunebaum:

In any case, not only is the rite of walking and running around a stone, an altar, or a sanctuary of any kind attested by pre-Islamic poetry in which wild kine are likened to virgins circling an idol, but can be traced 
in Jewish ritual in which at one time during the Feast of Tabernacles the altar was circled once on each of the six first days and seven times on the seventh. And in more recent times sevenfold circumambulation has become connected with the tombs of certain Muslim saints. (Grunebaum 1988: 29.)

Western scholars like Grunebaum obviously regard the circumambulation as an ancient rite with connections to superstitious traditions. The Muslims are ambivalent. If the rite existed earlier it can be said to have been originated by Abraham, but it must be understood in a new way after Muhammad. According to Muslim scholars Abraham had established the cult in Mecca but people had destroyed it by changing the way it was performed and Muhammad had to restore the correct cult:

The obligation of pilgrimage to God's sacred House, hence, goes back to the times of Abraham. Abraham then died, and after him his son Ismail. A long period of time passed, after which people stared to introduce forbidden acts of polytheism and idolatry or of circling the Ka'bah naked. God instructed Mohammed to put an end to such violations and sanctify the rites of pilgrimage from innovations and acts of heresy. (Tabbarah 1978: 173.)

Muslim scholars and theologians emphasize that people have ambulated around Kaba since it was built. Abraham had decided that it was an expression of genuine reverence to walk around it. After the time of Abraham it degenerated and was done as an expression of idolatry for a long time after the death of Ishmael and the appearance of Muhammad. The proof is that they then were naked and used it as an opportunity for business:

How Hajj was mutilated in that period of ignorance can be gauged from the fact that it was turned into a fair which used to be held from year to year. Many big tribes with their gangs used to come to Mecca and encamp there separately. ... There used to be circumambulation of Ka'ba but how? Women and men all went round and round stark naked and said: "We shall go before God in the same condition in which our mothers gave birth to us." Ibadat was performed in the mosque of Abraham but how? By clapping of hands, by whistling and by blowing horns. (Mawdudi 1978a: $211 \mathrm{f}$.) 
It is evident from this what is held to be unethical in the Muslim cult and culture. To be naked is very shameful and it is not accepted to make noise, particularly not by instruments like horns. So severely had the divine service decayed when God gave Muhammad the directing principles for restoration of the true form of Islam. The walking can, as in other pilgrimages, be accepted as an expression of piety. Noise and nakedness is a proof of superstitious attitudes. When they are eliminated, the circumambulation is 'clean' again and can be accepted. The problem is that the definition of the difference between superstition and piety seems to be arbitrary, adapted for the aim.

The circle ambulation is called tawaf and shall emphasize the relation between God and man: 'Tawaf is an acknowledgement of worship to God, submission and devotion to Him, as well as a reminder of the unity that keeps Muslims together' (Tabbarah 1978: 178). It is important to underline that tawaf is an expression of worship, submission and devotion. It is not a superstitious rite of reverence for the building or the place as axis mundi. Circumambulation might also be interpreted as an imitation of cosmic movements, which might be the origin of the following words: 'There is also a natural feeling of cosmic identity on the part of the pilgrim as he goes anti-clockwise around the cube-like structure of the Ka'bah' (Hamid 1990: 126).

These kinds of comments are very unusual nowadays. All associations with reverence for buildings, tombs and places on earth must be wiped out and replaced with 'submission', to Islam, to God and God alone. In the manuals for hajj it is seldom written that the pilgrims shall circle anti-clockwise. Perhaps the authors will avoid mentioning it as it might appear superstitious. Another rule is that the pilgrim shall go around the Kaba three times 'at a rapid pace and four at a normal walk' (Lippman 1982: 27). Details like these are often left out by Muslim authors of today and it seems obvious that they regard them as non-essential and perhaps fear misconceptions. It is apparent how Suzanne Haneef will underline the religious content of the circumambulation:

Moving in that sea of worshippers within the shadow of the Ka'aba, a deep sense of his smallness and insignificance comes to him, and all the trappings and defenses (sic!) of his ego fall away as he realizes that God alone is great and that none of his slaves can bring any of his worldly props and privileges with him to confront the glory and majesty of his Lord. Here, under the blazing sun of Mecca, making his circuits around God's Holy House as he repeats the solemn, moving supplications of the pilgrim, he comes face to face with his own nothingness, his creatureliness, his utter dependence on his Creator. (Haneef 1979: 54 f.) 
The typical trait of this text is the emphasis on the general religious experience. The pilgrim goes around together with millions of other Muslims to feel a deep sense of smallness and 'utter dependence of his Creator'. Seven times of circle ambulation, three fast and four at normal speed, seems completely unnecessary for this feeling and those rules are also omitted in Suzanne Haneef's account.

According to ancient traditions the pilgrim shall press himself against the multazam, the wall in Kaba which connects the eastern corner and the door. This is of special sanctity and it is there the devout press their breast and outstretched arms against the wall to become impregnated with Baraka, the blessing virtue, that is imminent in the holy building' (Grunebaum 1988: 23). Pressing the right cheek to the wall, the pilgrims are saying: 'O God, O Lord of the ancient house! Save my neck from hellfire!' (Klein 1979: 168). There has obviously been a conviction among people in Arabia, before and after the time of Muhammad, that Kaba is a holy building and that a physical contact with the walls of Kaba will give health and happiness.

It is a view of life and the world that is typical of magical thinking and it is easy to understand that the authors of today regard it as superstition and avoid mentioning it. It seems to have been a general custom and it may still exist, but when it disappears from the manuals it will probably come to an end also in the practical accomplishment, as far as it has not already. Today the numbers of pilgrims are so huge that this custom is difficult to perform, but it is also very hard to combine with the conviction that the circumambulation is an expression of reverence for God and not for the building.

\section{The Black Stone}

Muslim literature about hajj generally describes and discusses the importance of the black stone in the Kaba. The point is always to underline that the stone is of no religious importance (Lippman 1982: $26 \mathrm{f}$.). It is probably because non-Muslims (and perhaps also Muslims) have thought that the stone is holy in some way. That seems to be idolatry: 'The veneration of the Black Stone seems aberrant in a religion that professes to have avoided anything resembling idol-worship since the time of Mohammed' (Lippman 1982: 27, see also Mawdudi 1978a: 223). A book, distributed by the government in Saudi Arabia asserts: 
Muslims in no wise (sic!) worship the Black Stone. They kiss or touch it because it is known that the Prophet Muhammed did so and thereby they establish a link between themselves and the Prophet. And he did so because it was a link between himself and Abraham. (Quoted from Lippman 1982: 27.)

The stone has only one task, according to today's scholars, and that is to show where the circumambulation shall start (Tabbarah 1978: 173; cf. Haneef 1979: 54). Several authors write proportionately too much about the Black Stone, obviously anxious to eliminate misunderstandings:

The Black Stone requires a particular mention on account of the many misunderstandings on its score. It is not a meteorite, but a black stone. Its practical importance is to show the starting point of the circumambulation, and by its colour it is conspicuous in the building. Secondly, this stone is not worshipped, nor even do Muslims prostrate in the direction of this stone, prostration being done towards any and every part of the building of the Ka'bah. (Hamidullah 1974: 72.) ${ }^{1}$

The stone is a very unremarkable stone according to this author, but Muslims have chosen to use it as a sign of the correct starting point of circumambulation. According to a hadith, the Black Stone has been regarded as the 'right hand of God' which might be interpreted as God's way to indicate the starting point of the circumambulation. That is why men can express their loyalty to God by touching it. That is one of the attempts to make new interpretations of the stone and excuses for kissing it. The Muslim scholars underline that there is no obligation to kiss the stone. They cannot prevent the pilgrims from kissing the stone-or at least from trying to do it-but they can create a new and more edifying interpretation:

The Muslims go to Makkah to glorify God, not to kiss a stone or worship a man or semi-divinity. Kissing or touching the Black Stone at the Ka'bah is an optional action, not an obligation or prescription. They kiss or touch or point to the stone only as a token of respect or a symbol of love for Prophet Muhammad, who laid the stone at the foundation of the Ka'bah

1 Observe the number of the paragraph, 181/a. The author has fitted it into later editions, probably because of questions or objections. 
when it was reconstructed. That event has a special significance. It depicts Muhammad as a man dedicated to peace. (Abd al-Ati 1999: $98 \mathrm{f}$.)

Abd al-Ati then relates a story about a threat of civil war between chieftains in Arabia, caused by a fight about the honour of restoring the stone when Kaba was reconstructed. Muhammad 'decided to lay the Stone on a piece of cloth and asked the disputants to raise it together' (Abd al-Ati 1999: 99). They all accepted this Solomonic solution. Everybody was happy and Muhammad had once again proved that he was the model for a perfect human life. By means of this story about the background of the Black Stone, a beloved habit has been interpreted as an education in ethics. All suspicion of surviving superstition should be removed.

There are a lot of other traditions about the stone, its origin, history and importance. It is said that Abraham asked Ishmael 'to bring him a stone to fix it as a sign, from which people may start their circumambulation'. According to one tradition the Prophet Muhammad said: 'The Black Stone came down from Paradise whiter than milk, but the sins of Adam's offspring turned it black' (Tabbarah 1978: 173). It is also said that Muhammad venerated the stone because it had been touched by Abraham and Ismail:

The Prophet kissed it while circling the House, most probably because it was a trace from Paradise, or as a commemoration of the noble hands that carried it and placed it in its place, that is the hands of Abraham, the Grandfather of Prophets, and Ismail, the father of the Arabs. (Tabbarah 1978: 173.)

It is obvious from this text that every part of the hajj is used to repeat the content of the Muslim faith and worldview. The rites of Mecca shall create the connection between the original religion of Abraham and the revelations of Muhammad. All of them are situated in Mecca. Abraham is the most important prophet and Ishmael is called the Father of the Arabs. They prepare the ground for the Islamic message of Islam as the original and perfect religion of man. Two important parts of the pilgrimage are situated in Mecca, tawaf and $s a^{\prime} i$. There is a difference between them:

While the circumambulation of the Kaaba centres around God Most High, the centre of the drama of $s a^{\prime} i$ is man. Sa'i is symbolic of man's efforts and movements in life, of the human soul's ceaseless striving in his journey through the world, together with the host of his fellow human beings. The worshipper walks and during part of the way he may break into a run: seven 
times between the two lava-rock mounds, which are situated about a quarter of a mile apart, glorifying and supplicating God. (Haneef 1979: 55.)

The rites of Mecca are intended to underline man's relation to God. The circumambulation around Kaba is according to this text mostly directed to 'God Most High', and the running between the hills is a symbol of human life, of 'the human soul's ceaseless striving. So are heaven and earth, life and death, God and man all knit together and understood through the revelations of Prophet Muhammad, of the revelations he received in Mecca. It is not important to touch the Black Stone, to go around the Kaba or to run from Safa to Marwa. Only devotion to God is necessary. That is the message of pilgrimage. And it is worthy of notice that 'neither the Black Stone nor the Zamzam is mentioned in the Koran' (Hitti 1970: 38).

\section{The climax of the pilgrimage}

The most important part of the pilgrimage occurs on one set day in the month, dhu al-hidja, the last month of the Muslim year. Pilgrims might come to Mecca at different times to perform tawaf and $s a$ 'i. 'The pilgrim should arrive at Mecca by the seventh day of the month' (Lippman 1982: 26). The rites of Mecca are not the most important parts of the pilgrimage, although it might seem so, because Mecca and Kaba are such important places. But the most important part occurs two Swedish miles east of Kaba, at a set time:

However, the climax of the hajj occurs on the ninth day of Dhu al-Hijjah, the day of Arafat. The prophet (peace be on him) stressed the essential nature of this day's observance by saying that one who has been present at 'Arafat would have performed hajj, signifying that even if a pilgrim arrived too late to perform the initial rites at the Sacred House, still, as long as he had taken part in the assembly at 'Arafat, his hajj would be accepted by God. (Haneef 1979: 56.)

From this text we can conclude that it is very important to be at Arafat together. It is obvious that the gathering of all the pilgrims in one place on one set afternoon has a special importance. Arafat is a vast empty plain, treeless and barren, surrounded by black lava peaks. The pilgrims are gathered there over a rather long time. 'The halt at Ararat' is described in the following way: 
This is one of the basic rites of pilgrimage without which the Hajj becomes invalid, and the pilgrim's presence at 'Arafat should be during a specific period of time - from the noon of the ninth of Dul Hijjah till the daybreak of Yaum Al-Nahr (Day of Sacrifice). On this day, pilgrims come closer to God through supplication and earnest pleas. ... At 'Arafat, one sees worshippers devoting themselves to God, asking forgiveness, displaying submission, performing prayer, and some weeping - as if the plain has turned into a sacred lake where people can wash off their sins and wipe out their misdeeds. (Tabbarah 1978: 177 f.)

The programme and timetable of the pilgrimage is partly free and partly prescriptive. The time for the 'standing', wukuf, on the Arafat plain on the gth of Dhu al-Hudja is obligatory. No other day is permitted if you want to go to hajj. Millions of pilgrims move during the morning of that day from central Mecca to Arafat 'in order to spend the afternoon up to sundown engaged in penitence and supplication to God' (Haneef 1979: 56). They must be there at noon and they must not leave the plain until night has fallen. That means about six hours. After the pilgrimage, most Muslims agree that those hours are the most beautiful, impressive and overwhelming hours of their lives. This experience is motivated by the serious mood, the numbers of people in white clothes and the common attitude of reverence, submission and devotion. Suzanne Haneef writes:

During the afternoon up to sundown, all these human beings, assembled here from every land and belonging to countless races and cultures, are completely absorbed in supplication to God Most High, glorifying Him, affirming their utter helplessness and dependence on Him, and yearning for His forgiveness and His pleasure. (Haneef 1979: 56.)

It is obvious that the situation brings about a sense of dependency and reverence before the creator. Nobody can avoid this feeling when millions of Muslims are together at the same place. Surely they have all heard about the mood of Arafat from other pilgrims. The expectations are high. It is a very tense atmosphere:

The vast, otherwise empty plain is filled with. . .thousands upon thousands of pilgrims, tired and dishevelled and totally humble before their Creator, standing with hands raised in supplication, many weeping in the intensity of their awe and devotion to Him. Some climb up the Mount of 
Mercy, a hill in the middle of the plain from where the prophet (peace be on him) delivered his last hajj address to his people. (Haneef 1979: 57.)

Many authors emphasize the solemn and impressive atmosphere during this afternoon. This atmosphere is obviously caused by the idea of the Last Judgement, which seems to preoccupy everybody. People stand in front of the Mount of Mercy and listen to sermons. It seems to be like the Day of Resurrection, when the world comes to an end; all men will rise up from the earth and be called to the Lord of the Universe. According to general opinion (See also the Bible, Rev. 6:11), they will also wear white clothes. The Austrian Muslim Muhammad Asad (Leopold Weiss) has written:

Hidden from my eyes in the midst of this lifeless wilderness of valleys and hills, lies the plain of Arafat, on which the pilgrims who come to Mecca assemble on one day of the year as a reminder of that last assembly, when man will have to answer to his Creator for all he has done in life. How often have I stood there myself, bareheaded, in the white pilgrim garb, among a multitude of white-garbed, bareheaded pilgrims from three continents, our faces turned toward the Jabal al-Rahma - the Mount of Mercy - which rises out of the vast plain: standing and waiting through the noon, through the afternoon, reflecting upon that inescapable Day, when you will be exposed to view, and no secret of yours will remain concealed. (Asad, quoted from Hamid 1990: 128 f.)

It is obvious that most pilgrims think of the Last Judgement in front of the Mount of Mercy. They are filled with respect, esteem, and confidence in anticipation of the Judgement. They are convinced that their experience during this afternoon is an anticipation of the expected day in the future. This might fill the pilgrim with an awe of the coming examination:

The gathering of 'Arafat brings vividly to mind the immense gathering of that awesome Day when men's bodies will be brought out of their graves and rejoined with their souls and all will stand in utter humility before God Most High to await His judgment, a time when no soul will have anything to bring with it before God except its inner state and whatever little good it may have been able to do in this quickly-passing life. (Haneef 1979: 57.) 
They stand in front of the Mount of Mercy and a confident conviction of the merciful God seems to be the predominant feeling, or almost an obligation. It is said: 'The greatest sinner is he who stands on 'Arafat and believes that God has not forgiven him' (Tritton 1951: 28).

\section{The meeting of Adam and Eve}

According to traditions, the Mount of Mercy is the place where Adam and Eve met when they had been expelled from Paradise. This is a controversial story, but some authors reproduce it without any hesitation:

After their fall from Paradise, Adam and Eve were separated and lost. They searched for each other, and by the grace of God met together at 'Arafat. In gratitude to God, the descendants of Adam and Eve turn to Him, make an effort to forget themselves and be assimilated with the Divine Presence, with a view to entreat His pardon for their shortcomings in the past and His help for the future. (Hamidullah 1974: 72.)

Western authors generally refer the old tradition about Adam and Eve at the Mount of Mercy when they describe the Muslim pilgrimage (Stewart 1995: 91). Abdullah Yusuf Ali has given an overview of the duties in his translation of the Quran. Among the duties are

...the visit on the eighth (day of Dhu al-Hijjah), of the whole body of pilgrims, to the valley of Mina (about six miles north of Mecca), where the pilgrims halt and stay the night, proceeding on the ninth to the plain and hill of 'Arafat, about five miles further north, which commemorates the reunion of Adam and Eve after their wanderings, and is also called the Mount of Mercy. (Yusuf Ali 1979: 79.)

There is no support in the Quran for the tradition about the meeting of Adam and Eve on Arafat and for that reason it is nowadays under debate. Many scholars avoid mentioning it. ${ }^{2}$ Many Muslims are reluctant to accept this reformation of the holy history. They want to keep the connection between the first and the last day of the universe. The plain has been called 'Arafat before the time of Muhammad. The name means something like 'appear' and after 
the revelation of the Quran and the establishment of the 'new' Islam, Muslims began to interpret the word with reference to Adam and Eve. They met and recognized each other there, having wandered around on earth after the expulsion from Paradise. Present authors try to oppose the belief by giving new and more credible explanations of the name Arafat. One author refers to modern scholarship:

Maulana Muhammad 'Ali of Lahore, famed Muslim scholar and authority, describes the place, saying, 'Arafa or 'Arafat is the name of the plain which is situated to the east of Makkah at a distance of about nine miles. It is derived from 'arf or Ma'rifah, which means knowledge of a thing, and ma'rifah especially, means the knowledge of God. The name given to this plain seems to be based on the fact that here men assembled together, as equals in all respects, are best able to know their God. (Tabbarah 1978: 177.)

This is the very example of the ambition to teach Muslim doctrines during the pilgrimage. The standing at Arafat seems to be more serious if all the history of the world is embraced. The verb 'arafa has a lot of meanings, all connected with knowledge and understanding. Muslims in general appreciate wisdom and prudence. The Quran glorifies God as wise and exhorts human beings to use their reason. Everybody will then realize that there is a God and that we are responsible to him on the Last day. The author asserts that human beings can never know their God better than when they are assembled together on the Arafat plain. That is exactly what the theologians want every pilgrim to learn from pilgrimage.

There is a kind of intensification in the pilgrimage: Adam and Abraham are connected with the first days, Muhammad with the time in Mecca and then the Judgement with the afternoon at Arafat. But this climax must also be used to tie together the important elements of the religion. So creation and revelation must also be connected with this solemn moment. Creation is introduced by the idea of Arafat as the meeting-place for Adam and Eve. Revelation is naturally associated with the place because this is where Prophet Muhammad 'delivered his last hajj address to his people' (Haneef 1979: 57). This sermon is regarded as a kind of testament:

When the prophet Muhammad performed his own hajj, a few months before his demise, he uttered then from above the Hill of Mercy (Jabal alRahman) a sermon which constitutes the charter of Humanity in Islam. 
Some 1,40,000 [sic!] Muslims had come that year from all parts of Arabia, to listen to this testament of their Prophet. (Hamidullah 1974: 74.)

In this way a vault is built from the creation to the Day of Judgment, from the beginning to the end, and this total view of the world and the creation is present during the afternoon at Arafat, when millions of pilgrims stand in the hot sun in the desert. It might be easy to feel an 'utter humility before God Most High to await His judgment' (Haneef 1979: 57). When Muhammad started his preaching in Mecca, people could perhaps believe that there was only one God and that they ought to honour this God, but it was very hard to believe in life after death, and all the moral demands of the preaching depended on that point. It was necessary to stress that part of the message. It might be as necessary today. That is why Arafat is so important, to strengthen the central condition of Muslim faith.

\section{Stoning of Satan}

Abraham and the reference to his life return after the climax of Arafat might be understood as a way to teach the pilgrims how to prepare for the meeting with the judge of the Last day. After Arafat the pilgrims shall advance to Mina, where they shall perform the 'stoning of Satan' by throwing pebbles on 'three stone columns representing Satan which have stood since ancient times in the village of Mina' (Haneef 1979: 57). According to some authors Abraham did this in order to drive away Satan and his temptations:

As to the lapidation of Satan, it may be recalled that when Abraham claimed to love God above everything else, God demanded of him as a proof the immolation of his beloved son. To add to this trial, Satan went first to Abraham to dissuade him from this resolution - and they say that this happened at Mina - but Abraham chased Satan away every time by pelting stones on him. Then he went to Hagar, and lastly to Ishmael himself; each one of them did the same. So one repeats the act symbolically, and resolves to fight diabolic temptations. (Hamidullah 1974: 72.)

But also this is probably an invention of those who want to give an edifying interpretation of the custom. The quoted author says that Abraham really threw stones at Satan and Western textbooks about Islam might refer to this custom without any further comments (Esposito 1991: 93). But most modern Muslim 
books omit this element in their descriptions of the pilgrimage. ${ }^{3}$ Some of them mention it but never say that Abraham did throw stones at Satan:

At Mina, Jumrat-ul-Aqba, one of the pillars representing Satan, is pelted seven times, each time with ALLAH-O-AKBAR (Allah is the greatest) said aloud. These pillars are erected on the site where Abraham was tempted by Satan against offering Ishmael as a Sacrifice in the fulfilment of his dream. (Chaudhry n.d: 10.)

It is a kind of disinformation to repeat the old descriptions of this custom when it is so consciously opposed by contemporary Muslim scholars. And that is in no way only modern or liberal theologians. Maulana Mawdudi, known as a leading figure in the 'fundamentalist movement' (Enayat 1988: 101), emphatically rejects the old tradition of Abraham's stoning of Satan:

It is generally said that this act of flinging stones is done in commemoration of the incident which happened to Abraham i.e. when he was about to sacrifice Isma'il, Satan attempted to beguile Abraham who flung stones on him. Or, it is said, that when a goat was given to Abraham as a fidayah for Isma'il, the goat ran away and Abraham struck it with stones. But in no authentic Hadith has been narrated from the Holy Prophet (peace be upon him) that this is the background of Ramiyay-jimar. (Mawdudi 1978a: 225.)

Mawdudi tries to annihilate the idea about Abraham's stoning Satan. He obviously regards this as something completely impossible, unworthy the prominent prophet. He gives another explanation:

[The stoning] reminds of the destruction of that elephant army, which, in the year of the birth of the Holy prophet, invaded Mecca just in the month of Hajj, to demolish the House of Allah, and which, by the command of Allah, was destroyed by stone-raining sky-birds (Mawdudi 1978a: 225).

God can, according to Mawdudi, use the birds and stones to stop an invader, but Abraham is not a man who is throwing stones at Satan to evade his temptations. He has an inner struggle with the temptation and wins. Satan does not appear physically and flinging stones are not the way to drive him away. 
This is also an example of the ambition to find something valuable in traditions to connect with the doctrines, always with the purpose to teach and educate. It is valuable to fight against temptations. It is interesting to note that God frightened away the elephant army. It is more valuable in the face of the Last Judgement to frighten away Satan and his temptations. That seems to be the reason why Suzanne Haneef accepts the old association between Abraham and the pillars, however she avoids the old story and just gives it a religious reason:

The stone pillars stand at the sites where Satan appeared to Abraham and Ishmael (God's peace and blessing be on them) in remote antiquity, tempting them to disobey God when Abraham was taking his son to be sacrificed at God's command. On each of the three days of sojourn in Mina, countless numbers of pilgrims go to the columns, stoning them with the pebbles they have collected to symbolize their rejection of Satan, in a stirring drama of the endless human struggle against evil prompting and temptations. (Haneef 1979: 57.)

\section{Sacrifice of an animal}

The first day of stoning in Mina is also the first day in the Eid al-Adha (also written 'Idul Adha), the Feast of Sacrifice. It commemorates Abraham's readiness to sacrifice his son Ishmael (Sarwar 2003: 174). The pilgrims shall then make a sacrifice:

At this time, following the prophet's example and injunction, many of the pilgrims slaughter an animal in commemoration of Abraham's sacrifice of a sheep in the place of Ishmael; part of the meat is used to feed themselves and their group, and the rest is distributed among the poor (Haneef 1979: 57).

It is interesting that Suzanne Haneef writes that 'many of the pilgrims' perform this sacrifice, not all of them. There are also pilgrims who refrain from this part of the hajj tradition. It is obviously not obligatory, although we know that Prophet Muhammad really performed this sacrifice (Stewart 1995: 91 f.). It is perceived by the people that God wanted gifts such as animal blood and flesh; therefore this led to animal sacrifices. Who believes in this today? Should the sacrifice continue although the concept of God is different today? 


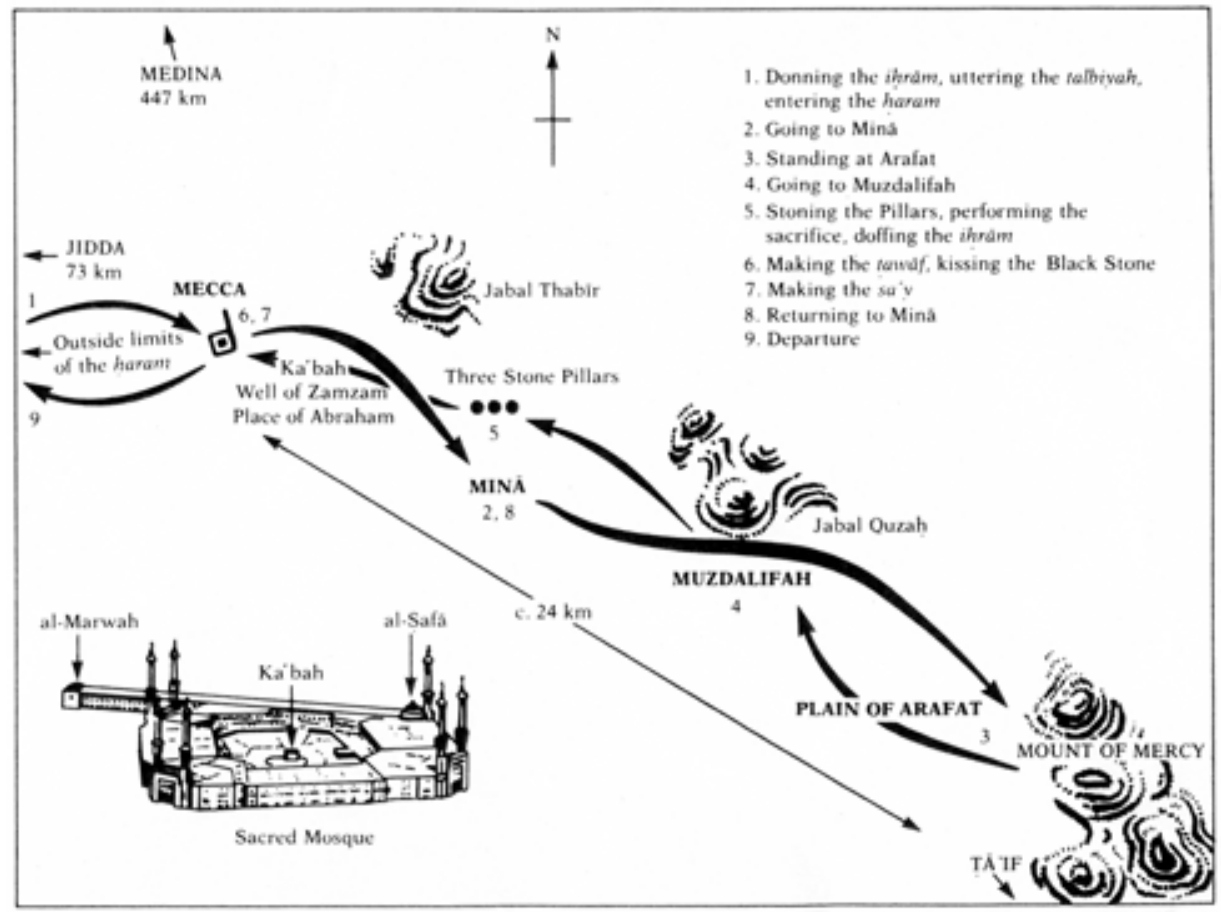

Sketch map of major points on the hajj (Eliade 1987: 343).

According to the Muslim authors, the belief that Allah demands flesh is wrong and Mawdudi condemns those who (before the time of Muhammad) thought that: 'The blood of the animals was spilt on the walls of Ka'ba and the flesh thrown at its door with the idea that, (may God forgive) Allah demands flesh' (Mawdudi 1978a: 212).

Western scholars often describe this as a sacrifice without any further information and it is easy to draw the conclusion that God demands bloody sacrifices. ${ }^{4}$ Muslim authors are anxious to interpret the sacrifice in an ethical and religious way:

In sacrificing such animals there is submission to God's command, and a demonstration of God's blessing by sharing the sacrifice with the needy....The Sacrifice that Moslems offer during Hajj, reminds them of

4 See, for example, Nigosian 2004: 112 and Waines 2003: 92, where the distribution of meat to the poor is mentioned. 
sincerity to God; it also carries a sense of thanksgiving to God for the ransom of Ismail. Through the salvation of Ismail there came the blessed line of descendents along which Mohammed was born. (Tabbarah 1978: 182.)

Suzanne Haneef thinks it is necessary to emphasize that the slaughtering of the sheep is not a sacrifice to God but is done in order for the meat to be eaten by perhaps starving human beings. It is an act of generosity. There are few virtues which are more valuable than generosity according to the Quran, so this distribution of food is something completely orthodox. The group of pilgrims and the poor in the neighbourhood should share the meat and in that way the sacrifice is interpreted as a symbol of economic equality. Hammudah Abd al-Ati is also anxious to emphasize that the sacrifice is not a gift to God but something else:

It is not the meat or blood of the sacrifice that pleases God. It is the expression of thankfulness to Him, the affirmation of faith in Him, and the remembrance of that historic event when Prophet Abraham was ordered to offer his son in sacrifice, an order which the father and son were ready to obey unquestioningly. (Abd al-Ati 1999: 101.)

Because this happens at a settled festival, Eid al-Adha, the sacrifice must be retained, but the interpretation should be more spiritually and morally educating. The ethical message is emphasised. The sacrifice is not obligatory, but when it is performed it is an expression of equality, generosity and solidarity with poor people. God needs nothing from us, least of all bloodied animals. In the time of jahiliyya, people might have thought that God wanted them as atonement. Muslims know that God forgives by mercy, not by human sacrifices.

\section{Return to Mecca}

The pilgrims are then free to return to Mecca for circumambulation after the first day of stoning, but they can also stay in Mina for another two days. According to the tradition they are obliged to throw stones on the satanic pillars on the 11th and 12th of the pilgrim month. Men are shaved; men and women have their hair cut: 
After the sacrifice the pilgrim's head is shaven, but women have their hair cut only slightly. This done, the pilgrim may discard the ihram. He is now freed from all but sexual restrictions. These are lifted only upon the pilgrim's return to Mecca, the third ifada of the hajj, on the same day as he is to perform a tawaf. He bathes and has himself sprinkled with Zamzam water before going back to Mina where he is to spend the nights of the eleventh to thirteenth of Dhu 'l-Hijja, the tashriq. ... These days are devoted to eating, drinking and sensual pleasures. The pilgrim is free to dispose his time, except that he is obligated to throw each day seven pebbles at each of the three Devils. (Grunebaum 1988: 34.)

Muslim writers describe the rites after Eid al-Adha in other words. Some of the Muslim authors mention the shaving, but nothing about the social life and sensual pleasures. Nor do they describe the bath or the sprinkling with Zamzam water:

It is desirable to have haircut or shaving of the head after the Sacrifice, and to proceed to Mecca to perform the circuits of the Ka'aba again, and then return to Mina, where seven pebbles are thrown at each of the three pillars Jumrat-ul-Oola, Jumrat-ul-Wasta and Jumrat-ul-Aqba), one by one (Chaudry n.d: 10).

The sprinkling with Zamzam water seems superstitious and no Muslim author has tried to give it a spiritual interpretation, as a symbol of a purification of sin or something similar. The shaving is also possible to be misunderstood and that might explain why it is not always mentioned in the descriptions of hajj. ${ }^{5}$

The hair-cutting and shaving may be perceived as a hair-sacrifice, which is often the origin. In Ancient Israel sacrifice of hair was common and it is written about the Nazirite in the Bible that he shall 'shave his head. . ., take the hair which had been dedicated and put it on the fire where the sharedoffering is burning' (Numbers 6:18). Also Apostle Paul performed a hair-sacrifice according to Acts 18:18. It is obvious that some Muslim writers avoid emphasizing the shaving and hair-cutting, probably for that reason. Sacrifices of that kind are a remnant from old times. They must be reinterpreted, but that seems more difficult and might explain why some authors have chosen to tone down the role of this rite. Suzanne Haneef writes: 'After the first day's 
stoning, the pilgrim may shower and return to his ordinary dress, and most prohibitions applying in the state of ihram are now lifted' (Haneef 1979: 57). To take a shower sounds modern and healthy. The old-fashioned idea of gaining power from the water of a holy spring is changed to a lesson in personal hygiene and health care.

\section{The idea of pilgrimage in Islam}

We have now followed the Muslim pilgrims through the rites of Mecca, Mina, Arafat and back to Mecca. It is time to summarize. What is the aim of the pilgrimage in Islam? The authors often repeat one purpose: peace. All Muslims are friends from their time of arrival at the pilgrimage and they have become even greater friends by the time of their departure from Arabia, after their visit to Mecca and Medina. According to Hammudah Abd al-Ati this is the first and most important purpose of hajj:

It is the largest annual convention of faith where Muslims gather to meet one another, study their common affairs and promote their general welfare. It is also the greatest regular conference of peace known in the history of mankind. In the course of hajj peace is the dominant theme; peace with God and one's soul, peace with one another and with animals, peace with birds and also with insects. To disturb the peace of anyone or any creatures in any way is strictly prohibited. (Abd al-Ati 1999: 97; cf. Tabbarah 1978: 175 f.)

This is a typical ideal of our time: peace and responsibility for the environment. It is also possible that it really is a contribution to peace, at least among Muslims. There are of course examples of this. Malcolm X has expressed it in the following way:

There were the thousands of pilgrims, from all over the world. They were of all colors, from blue-eyed blonds to black-skinned Africans. But we were all participating in the same ritual, displaying a spirit of unity and brotherhood that my experiences in America had led me to believe never could exist between the white and the non-white. (Hamid 1990: 128.)

But the opposite has also happened. Already in 692 Abd al-Maliks governor al-Hajjaj, led an attack against Mecca and set Kaba on fire (Afsaruddin 2008: 
83 f.). Nadir Shah reigned over Iran as Shah from 1736-47. He demanded the Ottoman Sultan to erect at the Kaba a fifth ritual place for the Shi' is and asked him to appoint a pilgrimage leader for Iranian pilgrims travelling to Mecca by way of Damascus. The Ottoman government rejected all the proposals (Enayat 1988: 40 f.). In modern times there have been riots in Saudi Arabia and one of them started in 1979 with an occupation of Kaba. The government sent for French troops, which captured the Kaba with gas and a lot of violence. Hundreds of people were sentenced to death as punishment. Peace might be an important purpose of pilgrimage to Mecca, but it has not always been achieved.

The second purpose of the pilgrimage according to Abd al-Ati is to demonstrate 'the universality of Islam and the brotherhood and equality of Muslims' (Abd al-Ati 1999: 98). It is a problem that the pilgrimage takes place in a state with serious problems in the relationship between poor and rich. Some inhabitants in Saudi Arabia might experience a provocation when they see how poor immigrants must work for a low salary and how the rich élite will become still richer because of the pilgrims. But the ihram-dress and all the equal obligations of the pilgrimage might strengthen the feeling of equality, especially during the standing at Arafat. All Muslims stand immediately before their God in the same way as on the Last day and they anticipate the feeling of absolute equality and absolute righteousness in the Judgement, just as it is expected to be on that day.

The third purpose repeats and emphasises this trait of Muslim faith. Its aim is to confirm the commitment of the Muslims to God and their readiness to forsake material interests in His service (Abd al-Ati 1998: 98). As purpose number four, Abd al-Ati counts acquaintance with 'the spiritual and historical environment of Prophet Muhammad, so that they may derive warm inspiration and strengthen their faith'. The following two points are tightly connected with this. They shall 'commemorate the Divine rituals observed by Abraham and Ishmael' and lastly, the pilgrimage 'is a reminder of the Grand Assembly on the day of Judgement, when people will stand equal before God, waiting for their Final Destiny' (Abd al-Ati 1999: 98).

Among these six purposes of the hajj the confirmation of the Muslim's commitment seems to be the most important. Peace is perhaps the most urgent worldly and temporal purpose of the pilgrimage, although sometimes in vain, and it is often mentioned as the primary purpose (Tabbarah 1978: 175). But the result which is realised is the increased commitment and strengthening of the Muslim faith. This is due to the modern interpretation of and education about the pilgrimage. The pilgrims shall constantly repeat a prayer, called talbiya, which begins with the word labbayka: 
The talbiyyah or the special refrain announcing man's willingness and eagerness to acknowledge and obey God resounds throughout the Hajj environment:

Here I am, O Lord, here I am! Here I am; no partner hast Thou; here I am! Surely to Thee is all Praise, all goodness and all Sovereignty No partner hast Thou! (Hamid 1990: 129.)

This prayer is repeated as a kind of mantra. It might seem mechanical and superficial, but authors of today regard this talbiya as a summary and central expression of the whole pilgrimage. It is an old tradition and used at every part of the hajj, but today it is especially used to increase the importance of the standing at Arafat at the expense of other rites during the hajj. This labbayka inculcates the relation of dependence between man and God and that relation is regarded as most manifest in the wukuf. The authors emphasise the fact that this standing must be the essence of pilgrimage as it is the only part which is obligatory and must take place at a set time. All pilgrims must stand there in the burning sunshine for six hours.

\section{Pilgrimage as central rite}

Why has pilgrimage been a central part of Islam and counted among the so called five pillars? Of course it is a way to remember Abraham and repeat the pretensions of Islam to be the original religion of mankind and the restored religion of Abraham. The pilgrimage has always been used as a means of educating Muslims in the creed and content of Islam-and that message might change over time. For that reason the pilgrimage also presents a mirror of the current Muslim preaching and theology. In our time the message of Islam as the religion of reason and nature is important. It is emphasised in conscious opposition to old rites which might be interpreted as superstitious. It is necessary to underline that nobody knows if they ever have been perceived in that way, but this suggestion is at least implicated in some Western descriptions of the hajj. The suspicion is enough for the ambition of Muslim scholars to tone down the role of several elements of the pilgrimage.

Muslim pilgrimage is not only-and not in the first place-penitence and it is hardly a compensation for sins. It is a way to forgiveness and reconciliation, but it is above all the Annual International Muslim Assembly (Sarwar 2003: 74) and is used for education and demonstration of the Muslim creed, a confirmation of convictions about Islam as the eternal, universal, rational and 
natural religion. It serves the same religious purpose as the mass meetings of revivalist movements among Christians. The environment and ecological prerequisites support the aim during the standing at the plain of Arafat during the appointed day when every pilgrim must be present at the same place, from noon to sunset.

The desert, the roof of heaven, and the heat combined with the memory of creation and association with the last Judgment make Muslims feel humble and submissive. It might be contributions to penitence: At 'Arafat, one sees worshippers devoting themselves to God, asking forgiveness, displaying submission, performing prayer, and some weeping-as if the plain had turned into a sacred lake where people can wash off their sins and wipe out their misdeeds' (Tabbarah 1978: 178). Many pilgrims describe the hours at Arafat as the most terrific experience of their lives so it is obvious that this penitence is the most impressive impact of the pilgrimage.

To a certain degree the pilgrimage is a denial of convenience but not overly so. It is of course a hard experience to stand in the sun praying and listening to sermons, but this mortification helps the pilgrims to feel that they really offer a sacrifice to God. Disabled people do not need to stand in the sun but may stay in tents. Nobody shall be tried over capacity. But the most evident result of the standing at Arafat is the strengthening of the Muslim faith in God and the Judgement. Four million Muslims stand for six hours with lifted hands repeating the expressions of commitment. The preaching of the Prophet is read from the Mount of Mercy, where people still believe that Adam and Eve met at the moment when Islam was brought to the earth. The creation and the destruction of the universe are knit together.

\section{Pilgrimage and the content of Islam}

Let us now return to the statement of von Grunebaum, who declared that 'nothing in the doctrine of Islam suggests the wuquf in 'Arafa as the culmination of a specifically Muslim pilgrimage' (Grunebaum 1988: 35 ). He is completely correct in his statement that the wuquf in Arafat is the climax of the pilgrimage. He is completely wrong, however, when he thinks that the climax of the standing at Arafat is incompatible with what he calls the doctrine of Islam'. If there is anything which might be called 'doctrine of Islam' there is at least nothing which can be appointed 'the doctrine of Islam'. Perhaps Grunebaum meant that the doctrine of Islam is a message about the revelations of Muhammad and certain rites prescribed in the Quran. Then it might 
be a strain to regard the standing at Arafat as 'the culmination of a specifically Muslim pilgrimage' and more Islamic if the circumambulation around the Kaba was regarded as the most important rite.

Doctrines differ over time, however. For the moment, most scholars want to emphasise the doctrine of Islam as the original and natural religion of mankind. Nothing can then be more helpful in an education by experience in that creed than the experience of standing at Arafat. Today it is easy to see why standing at Arafat is regarded and emphasised by Muslim authors as the most important part of the pilgrimage. It is the most significant expression of man's situation as a human being between creation and Judgement. According to modern Muslim scholars Islam is the original religion of mankind.

The standing at Arafat has a symbolic importance. The sky is a symbol of God, creator and protector, on which all life depends. The Mount of Mercy reminds the pilgrims of Muhammad, who gave us the guide to a life according to the will of God. Millions of Muslims in white clothes show us the situation on the day of Judgement. That is also the reason why modern Muslims try to extinguish or decrease the importance of all customs which seem to reflect an old Semitic or Arabian religion, or at least everything which might be understood or misunderstood as superstition. It is valuable to visit Mecca because you can learn the story of Adam, Abraham, Ishmael and Muhammad. They are the most important prophets of human history. Every part of that story is told and interpreted in a timeless way, however, as an expression of a view of life, and not as events or incidents in past history.

During the pilgrimage people leave the milieu of their everyday life and spend some weeks in a completely different environment together with millions of like-minded people. The attitude and atmosphere might also be described in a more militant way:

The Ka'bah at Makkah is the spiritual center of Islam and the spiritual homeland of every Muslim. When the pilgrim reaches Makkah his feelings would be like those of a patriot coming home from exile or a triumphant soldier returning from a decisive battle. (Abd al-Ati 1999: 99.)

This seems to be a typical opinion about Muslim pilgrimage. It means a victory. The army of four million Muslims have defeated doubts and weakness. Mecca is their spiritual homeland but they also have a worldly home and return there as victorious, still more strengthened in their belief that their God is the God of the universe and that their faith is the universal religion. They are educated by a number of experiences and their belief in Islam as the su- 
perior, perfect and conclusive religion is even more consolidated. They return home with the conviction that four million people cannot be wrong.

\section{References}

\section{Abd al-Ati, Hammudah}

1999 Islam in Focus. Riyadh: International Islamic Publishing House.

Afsaruddin, Asma

2008 The First Muslims: History and Memory. Oxford: Oneworld.

Armstrong, Karen

1993 Muhammad: A Biography of the Prophet. San Francisco: HarperCollins.

\section{Chaudry, Rashid Ahmad}

n.d. Mosque: Its importance in the life of a Muslim. London: The London Mosque.

Eliade, Mircea (editor in chief)

1987 The Encyclopedia of Religion. Vol. 11. New York: MacMillan Publishing Company.

\section{Enayat, Hamid}

1988 Modern Islamic Political Thought. London: Houndmills.

\section{Esposito, John L.}

1991 Islam: The Straight Path. Oxford: Oxford University Press.

\section{Geaves, Ron}

2006 Key Words in Islam. London: Continuum.

Grunebaum, G. E. von

1988 Muhammadan Festivals. London: Curzon Press.

\section{Hamid, Abdul Wahid}

1990 Islam, the Natural Way. London: MELS.

\section{Hamidullah, Muhammad}

1974 Introduction to Islam. Lahore: Kashmiri Bazaar.

\section{Haneef, Suzanne}

1979 What everyone should know about Islam and Muslims. Chigaco: Kazi Publications.

\section{Hitti, Philip K.}

1970 Islam: A Way of Life. South Bend, IN: Regnery/Gateway, Inc.

Klein, F. A.

1979 The Religion of Islam. London: Curzon Press. (First published in 1906.)

Lippman, Thomas W.

1982 Understanding Islam. New York: Times Mirror.

Mawdudi, Abul Ala

1978a Fundamentals of Islam. Lahore: Islamic Publications Limited.

1978b Towards Understanding Islam. Lahore: Idara Tarjuman-ul-Quran. 
Nigosian, S. A.

2004 Islam: Its History, Teaching, and Practises. Indianapolis: Indiana University Press.

\section{Sarwar, Ghulam}

2003 Islam, Beliefs and Teachings. London: The Muslim Educational Trust.

Stewart, P. J.

1995 Unfolding Islam. Reading: Garnet Publishing.

Tabbarah, Afif

1978 The Spirit of Islam. Beirut: Libraire du Liban.

Tritton, A. S.

1951 Islam: Belief and Practices. London: Hutchington's University Library.

Waddy, Chris

1982 The Muslim Mind. London: Longman.

Waines, David

2003 An Introduction to Islam. Cambridge: Cambridge University Press.

Wellhausen, Julius

1927 Reste arabischen Heidentums. Berlin: Walter de Gruyter \& Co.

Yusuf Ali, Abdullah

1989 The Holy Qur'an. Text, Translation and Commentary by 'Abdullah Yusuf 'Ali. Brentwood, MD: Amana Corporation. 